\title{
Russian IMAGES activities during 1997 and 1998
}

Russian paleoceanographic research linked to IMAGES is coordinated at the Shirshov Institute of Oceanology (SIO), Russian Academy of Sciences in Moscow. The team includes Drs. M. Levitan (the official Russian representative to IMAGES), E. Ivanova, and I. Murdmaa. About 10 scientists are investigating IMAGES related questions both at the SIO as well as its Atlantic (Kaliningrad) department. In addition, the following institutes are also involved: Pacific Institute of Oceanology Far East Branch in Vladivostok, (Dr. S. Gorbarenko); Moscow State University (Drs. Y. Polyakova and S. Nikolaev); Institute of the Lithosphere in Moscow (Dr. O. Naidina); and Murmansk Institute of Marine Biology (Dr. G. Matishov).

Russian paleoceanographic activities during 1997/1998 were mainly concentrated in two regions: the Arctic and Far-East seas. Four cruises of the R.V. Akademik Sergei Vavilov (SIO) were carried out in the Barents (Cruises 11, 13, and 14) and Norwegian (Cruise 12) Seas. The programs of these cruises included studies of present and past thermohaline circulation in the region, as well as faunal and sedimentological responses to Late Quaternary climatic changes. Altogether 37 gravity cores, up to $6 \mathrm{~m}$ long, were collected and sampled for paleoceanographic studies (including lithology, geochemistry, micropaleontology, mineralogy and isotopy). Paleomagnetic study of selected cores from the Barents Sea was carried out during Cruise 14 by specialists from the All-Russian Research Institute of Ocean Geology (VNII Okeangeologiya, St.-Petersburg) and the All-Russian Institute of Geology (VSEGEI, St.-Petersburg). Most of the cores from the Barents Sea recovered sedimentary records of the Holocene and last deglaciation. The materials collected are now the subject of geochemical, micropaleontological, and sedimentological studies being undertaken at the Shirshov Institute of Oceanology. The results will be used to reconstruct paleoenvironments, in particular Atlantic water inflow into the region during postglacial time.

Detailed investigations of the history of the Laptev Sea and eastern Siberian river discharges since the Last Glacial Maximum were performed by research-

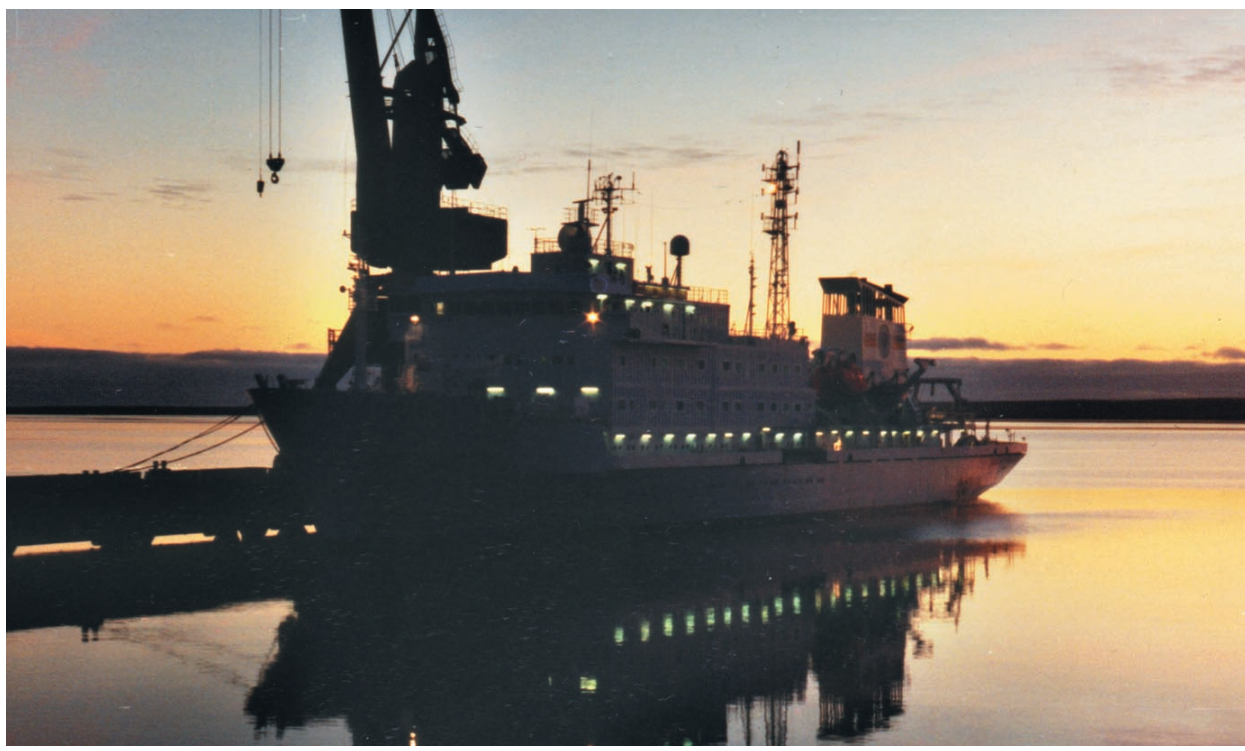

R.V. Akademik Sergei Vavilov

ers from the Institute of the Lithosphere and Moscow State University as part of a joint Russian-German project on the exploration of the climatic system of the Laptev Sea. High-resolution paleoceanographic data from the Sea of Okhotsk were recently obtained by scientists from the Pacific Institute of Oceanology in cooperation with colleagues from the Shirshiov Institute of Oceanology and the USA.

Preliminary results of this Arctic research were published in the abstract volumes of two meetings "Quaternary problems and perspectives for the next century" (St.-Petersburg, September, 1998) and "Marine Periglacial and Glaciation of the Barents-Kara Sea shelf in the Pleistocene" (Murmansk, November, 1998). In addition, during the last year Russian paleoceanographers discussed their work at the International School on Marine Geology (Moscow, October, 1997), at two sections of the $6^{\text {th }}$ Zonenshain Memorial Conference (Moscow, February, 1998) and at the $6^{\text {th }}$ International Conference on Paleoceanography (Lisbon, August 1998).

Several Russian scientists involved in IMAGES participate in international co-operative projects with German (project KOMEX), French ("The Arctic seas influence on thermohaline circulation in the North Atlantic"), Norwegian (Arctic paleoceanography) and American (sea-surface temperature reconstructions in the Western Equatorial Pacific and Sea of Okhotsk studies) colleagues.
Since 1993, Siberian scientists from the Limnological Institute, Siberian Branch in Irkutsk, led by Dr. M. Grachev have played a very active role in the International Baikal Drilling Project. The results obtained to date include a detailed climatic record of the last 250,000 years, based on micropaleontological, mineralogical, geochemical and paleomagnetic studies in the upper 50 $\mathrm{m}$ of the sediment sequence. The climatic oscillations revealed are comparable with those in marine records.

Looking to the future, in 1999, Russian paleoceanographers will host an international workshop (co-funded by IMAGES) to discuss the problems and perspectives involved in correlating high-resolution records from the Arctic and Far East seas.

\section{Elena Ivanova and Ivar MurdmaA}

Shirshov Institute of Oceanology, Russian Academy of Sciences, Moscow, Russia eivanova@geo.sio.rssi.ru murdma@chip.sio.rssi.ru

\section{All PAGES-Publications are} available both as hardcopy and in electronic form from: http://www.pages.unibe.ch/ publications/publications.html 